\title{
University-School Divide: The Original Problem in Teacher Education
}

\author{
Boris Krichevsky ${ }^{1}$ (D)
}

Received: 5 January 2020 / Revised: 2 April 2021 / Accepted: 4 April 2021

(c) The Author(s), under exclusive licence to Springer Nature Switzerland AG 2021

\begin{abstract}
This paper focuses on the origins of the university-school divide in teacher education. For decades, the weakness of communicative and collaborative links between the university and K-12 system has been one of the most significant barriers to effective preparation of new teachers identified by researchers and policy makers. Historical obstacles, such as disconnects between coursework and field work, divides between professional knowledge and skilled practice, and competing goals and priorities between organizations continue to plague the work of teacher preparation. The problem of the university-school divide in teacher education is further surfaced by scholarship that points to benefits of embedding teacher preparation in the K-12 setting and burgeoning research that suggests clinical practice is central to high-quality teacher preparation. This paper presents a case study investigating the organizational contexts of the university-school relationship in a teacher education program and draws on third-generation activity theory and activity system analysis to explore the evolving partnership institutionally, culturally, and historically. Findings reveal that transactional relationships between system elements shape collaborative activities and partnerships and show multilevel contradictions within and across collective activities, suggesting potential for expansive development.
\end{abstract}

Keywords CHAT · University-school partnerships · Activity theory · Teacher education

"The necessary joining of K-12 and university cultures brings with it virtually every problem documented in the literature of educational change. Yet it is a long-overdue effort that is here to stay. There is likely to be no turning back as what is now more talk than action becomes a common feature of the teacher education enterprise."

(John I. Goodlad, School-University Partnerships and Partner Schools, 1993)

Nearly three decades ago, John Goodlad imagined the future of teacher preparation as becoming a joint effort shared by the K-12 and the university systems. Writ large, the "talk" about collaboration between the K-12 school systems and teacher education programs has indeed evolved into "action." Partnerships between schools and universities are now commonly featured in teacher education programs across the country. The benefits

Boris Krichevsky

bkrich@uw.edu

1 University of Washington, 211 Miller Hall, Seattle, WA 98195, USA 
of a collaborative relationship between teacher preparation programs and schools are well documented in the literature. A report by the National Council for Accreditation of Teacher Education Blue Ribbon Panel (2010) calls for clinical practice, set in schools, to be centered in all teacher preparation efforts. Similarly, the American Association of Colleges for Teacher Education Clinical Practice Commission (2018) highlights the value of embedding teacher preparation in the PK-12 school setting, noting that "clinical [school-based] practice is central to high-quality teacher preparation" (p. 13). However, while universityschool partnerships are solidified components in teacher preparation, the problems-old and new-brought forth by such partnerships continue to disturb the field of teacher education. This issue, often referred to as the university-school divide or gap, is considered a perennial challenge for the teacher preparation enterprise (Cochran-Smith, 2008; FeimanNemser \& Buchman, 1985; Fullan et al., 1998; Zeichner, 2007).

Extensive scholarship demonstrates that the university-school divide is historically rooted, multifaceted, and persistent (Martin et al., 2011; Murrell, 1998; Smagorinsky et al., 2003; Zeichner, 2010). Research shows that misalignments between the content of teaching-and-learning, as provided by the teacher preparation programs, and the practice or enactment of teaching, as it takes place in the K-12 schools, typically result in preservice teachers struggling to make connections between theory and practice (Goodlad, 1990b; Korthagen \& Kessels, 1999; Shulman, 1998). Additional studies indicate that mismatches in the sets of goals and priorities between organizations and participants can harm the university-school relationship and jeopardize the quality of teacher preparation (e.g., Ballantyne \& Packer, 2004; Grundy et al., 2001; Shinners, 2001; Teitel, 1997; Zeichner \& Conklin, 2005; Zeichner, 2012).

This article considers the university-school divide as the original problem in modern teacher education. Drawing on the extant literature on the university-school divide, I present a qualitative case study I conducted on a partnership between an elementary teacher education program and a public elementary school. The purpose of this research is to analyze the university-school relationship culturally, historically, and institutionally and examine the impact organizational structures have on the university-school relationship. To this end, the university-school relationship is conceptualized as a partnership between separate yet interacting and collaborating human activity systems with potentially shared goals. Research and data analyses were guided by third-generation activity theory (Engeström, 1999a, 2001). Findings revealed two central themes on the university-school divide in teacher education: first, the presence of multiple and at times competing motives and objects contributed to tensions between the two activity systems; second, organizational structures within and across activity systems afforded and constrained how the partnership engaged the found tensions.

\section{Review of the Literature}

The university and P-12 school systems are interconnected and interdependent (Goodlad, 1988, 1990a; Hathaway, 1985) and share the challenge of developing quality teachers (Goodlad, 1991; Holmes Group, 1995). Collaboration between teacher educators, mentor and cooperating teachers, teacher coaches, and other members of the teacher preparation community as they jointly guide the development of pre-service teachers is generally accepted to be valuableat least conceptually — by the field of teacher education (Darling-Hammond, 2010; Zeichner, 2010). Historically, the relationship between the university and public-school system has been 
ambivalent, with student-teachers reporting sharp differences between what they are taught in courses and what they experience in K-12 classrooms (Goodlad, 1990b). Misalignment of coursework content with opportunities to enact the learned concepts in the field (Bullough et al., 1999; Feiman-Nemser \& Buchman, 1985) and disjointed clinical components within teacher preparation (Vick, 2006) seem to jeopardize the efficacy of teacher education. Additionally, disconnects between the campus and field-based components of teacher preparation programs continue to create obstacles to pre-service teacher learning (Zeichner, 2010) and contribute to the under-preparedness of novice teachers.

As Grossman (2010) writes, effective collaboration across organizations requires bridging several divides, for example, between professional knowledge and skilled practice, between universities and P-12 schools, and between the settings in which prospective teachers learn and the contexts of their early years of teaching. Addressing these challenges is critically important, as research on university-school partnerships in teacher education demonstrates that ineffective partnerships have a negative impact on the preparedness of novice teachers (Darling-Hammond, 2006; Zeichner, 2012). As such, the field of teacher education has undertaken numerous development efforts aimed at examining and improving this relationship. Lines of research include investigating student teaching with an ecological approach (Valencia et al., 2009), studying the process of student teaching placement and mentor teacher matching (St. John et al., 2018), and developing practice-based models for teacher preparation (Darling-Hammond, 2006; Zeichner, 2010, 2012). Additionally, the field of teacher education has undertaken numerous promising initiatives aimed at examining and improving the university-school relationship (e.g., Centers of Pedagogy and Professional Development Schools). Overall, such efforts are often university-centric, leading scholars to voice concerns that the approaches replicate if not reify the power-knowledge hegemony of traditional teacher education and contribute to an imbalance in the universityschool relationship (Murrell, 1998; Zeichner, 2009).

\section{Theoretical Framework}

Cultural-historical activity theory is rooted in the work of Vygotsky [Выготский] (1978) and the Russian cultural-historical school (Leont'ev [Леонтьев], 1978; Luria [Лурия], 1979). Vygotsky suggested that there is an essential relationship between the minds' processes and how the mind interacts with cultural, historical, and institutional settings (Rogoff, 1990; Yamagata-Lynch, 2010). For Vygotsky, this relationship explained human activity and learning, which consisted of individuals engaging in meaning-making through interactions with others, while concurrently drawing on and creating activities which transform artifacts, tools, and other individuals (Yamagata-Lynch, 2010). Vygotsky (1978) claimed that every human activity has a goal, which he referred to as the object. As Engeström (2001) explains, Vygotsky understood objects as cultural entities, meaning they can be influenced by the subject. The process of the subject creating and working toward the object is facilitated with mediating artifacts or tools, which include physical items, other individuals, and subject's prior knowledge. This approach to human activity allowed Vygotsky to shift away from viewing human development as a dualistic stimulus-response model and capture the dialectical nature of learning situations (Yamagata-Lynch \& Haudenschild, 2008). This concept of human activity is typically represented as Vygotsky's basic triangle (Cole, 1996; Cole \& Engeström, 1993), which depicts the structure for mediated action. Figure 1 provides an illustration of the mediated triangle, which attempts to explain human 
Fig. 1 Vygotsky's basic mediated action triangle adapted from Cole and Engeström (1993)

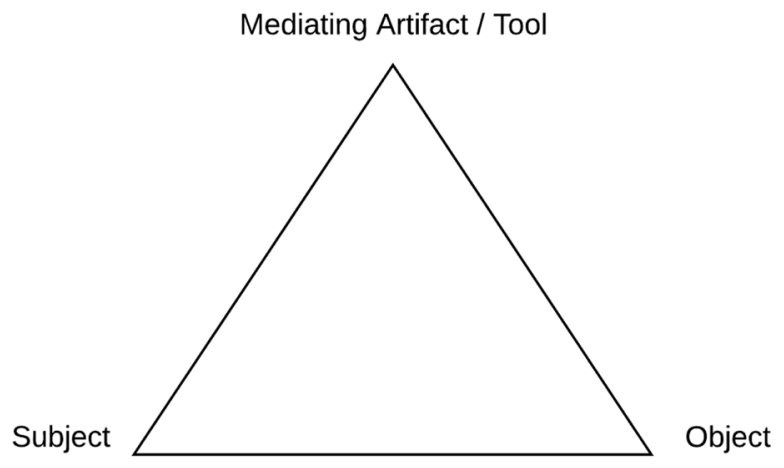

consciousness development by capturing the dialectic interaction between individuals and the world through mediated action (Yamagata-Lynch, 2010).

Vygotsky was primarily concerned with the meaning making process of the individual, and the basic mediated action triangle is typically referred to as the framework for firstgeneration cultural historical activity theory (CHAT). Leont'ev (1978) expanded the focus of activity theory from the individual to collective activity, identifying object-oriented activity as the unit of analysis to be examined. Leont'ev (1978) defined object-oriented activity as:

...A unit of life, mediated by psychic reflection, the real function of which is that it orients the subject in the objective world. In other words, activity is not a reaction and not a totality of reactions but a system that has structure, its own internal transitions and transformations, its own development... In all of its distinctness, the activity of the human individual represents a system included in the system of relationships of society. Outside these relationships human activity simply does not exist. (p. 85)

The work of Leont'ev and his colleagues examined the endlessly multifaceted and varied nature of human activity and sought to analyze the development of consciousness within practical social activity settings (Daniels, 2004).

Engeström (1987) refers to this framework as the second generation of cultural-historical activity theory. By emphasizing the collective nature of human activity, second-generation CHAT enables activity theorists to take a collective object-oriented activity system as its prime unit of analysis (Engeström et al., 1999a, b) and examine activity as it is realized in goal-oriented individual and group actions (Jahreie \& Ottesen, 2010; Engeström et al., 1999). To this end, CHAT draws on the Vygotskian idea that human consciousness and practical activity are interconnected, "where human activity is mediated by physical or psychological tools" (Ellis et al., 2010, p.2).

As a conceptual tool, CHAT is helpful for understanding relationships between the subjectivity of people trying to act on an object, by providing a framework for representing the interrelated and co-produced elements of activity systems. In examining the significance of mediation within activity theory Cole (1996) notes, "the Russian cultural-historical school considered the structure and development of human psychological processes to emerge through culturally mediated, historically developing, practical activity" (p. 108). The structure of second-generation CHAT is often represented by Engeström's (1999b) Sierpinskitype triangle. As Fig. 2 illustrates below, second-generation CHAT explicitly articulates the dialectical relationship between the individual subject and the collective (Bakhurst, 2009; Roth, 2007) and highlights the fact that researchers cannot understand the action of a 


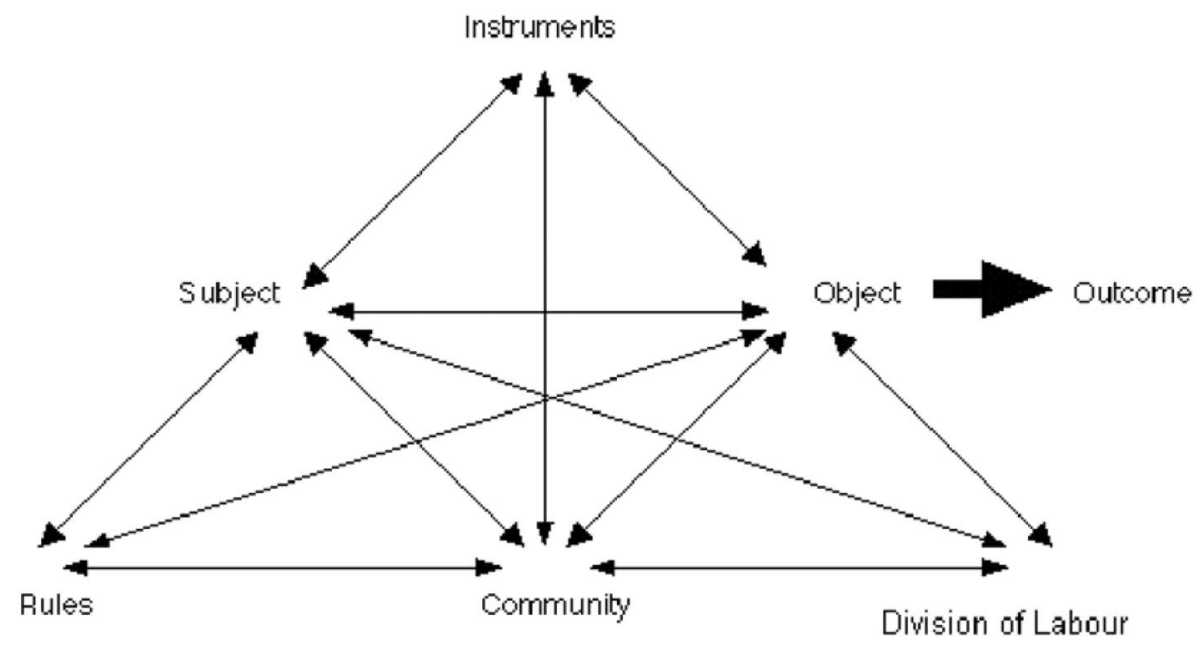

Fig. 2 Activity system model adapted from Engeström (1987)

subject on the object of activity outside of "all the relations to other aspects of the activity, which mediate every other moment and relation" (Roth, 2012, p. 88).

The second-generation CHAT framework consists of six such interrelated elements or nodes: subject, object, tools, rules, community, and division of labor. Konkola et al. (2007) describe these elements, interpreted in the context of teacher education:

The word subject refers to the 'individual', e.g. an instructor, whose point of view is adopted in the analysis. The object refers to the 'problem area' to which the activity is directed. The object of the activity is oriented toward a particular goal and is transformed to produce outcomes. Tools or mediating instruments, which are either found or created, shape the activity and help achieve results. Tools are understood here as mental or material, e.g. learning strategies, syllabi, or assessments. Rules refer to the explicit or implicit regulations that constrain actions. For instance, rules could be the degree regulations that govern the actions of the instructors. Community denotes all the participants, e.g. program directors, program instructors, teacher coaches, and cooperating or mentor teachers who share the same object in an effort to produce change in the object. Division of labor refers to the distribution of tasks, authority and benefits among these participants. (p. 214)

Additionally, activity theory captures the dynamic relations between the elements. As Foot (2001) explains, the "subject" and the "community" can evolve and interchange during the activity,

In activity theory terms, one or more members of a group engaged in collective activity at any given moment may be viewed as a subject engaging the object of the activity through a particular action. Those who are part of the group oriented toward the same object, but are not engaging in that specific action, are referred to as members of the "community of significant others." Throughout the course of an activity, the actual persons constituting the subject(s) and members of the community may thus interchange their "roles" frequently. (p. 61). 
To summarize, the CHAT framework asks to what extent actors who are working together in an organization understand what they are working toward, how the actors are developing a shared subjectivity of the object, and how the elements of the activity systems interact.

\section{Third-Generation Activity Theory}

As Engeström et al. (1999a, b) explain, activities are purposeful interactions of the subject with the world, a process which involves mutual transformations of the subject and object. However, in divided multi-activity fields where multiple organizations interact (e.g., healthcare, education, social services), learning takes shape as renegotiation and reorganization of collaborative relations and practices, and as creation and implementation of corresponding concepts, tools, rules, and sometimes entire infrastructures. These processes occur within and between agencies. To study more than one activity system, specifically the interaction of two or more activity systems, Engeström (1999a, 2001) developed third-generation activity theory. Third-generation activity theory aims to represent the multivoicedness of actions and ideas by recognizing the joint activity or practice as the unit of analysis (Daniels, 2004; Ellis et al., 2010). Activities within third-generation CHAT are considered social practices, oriented at objects (Engeström, 1999a). This allows the researcher to capture the evolving identities of members and their interactional relationships, and analyze multiple networks of interacting systems (Engeström, 2001). This theoretical framework attempts to dialectically link the individual and the social structure by examining the influences within and across activity systems (Engeström, 1999b), and allows for analysis of human activity based on inquiries into new concepts and models for human activity (Yamazumi, 2006). Figure 3 depicts two activity systems seen through the third-generation CHAT framework.

As shown in Fig. 3, the two activity systems are bound by the shared object $\left(\right.$ object $_{3}$ ). Yamagata-Lynch and Haudenschild (2008) expand on this concept, "the relationship between the two activities can trigger a chain reaction of mediated actions within the

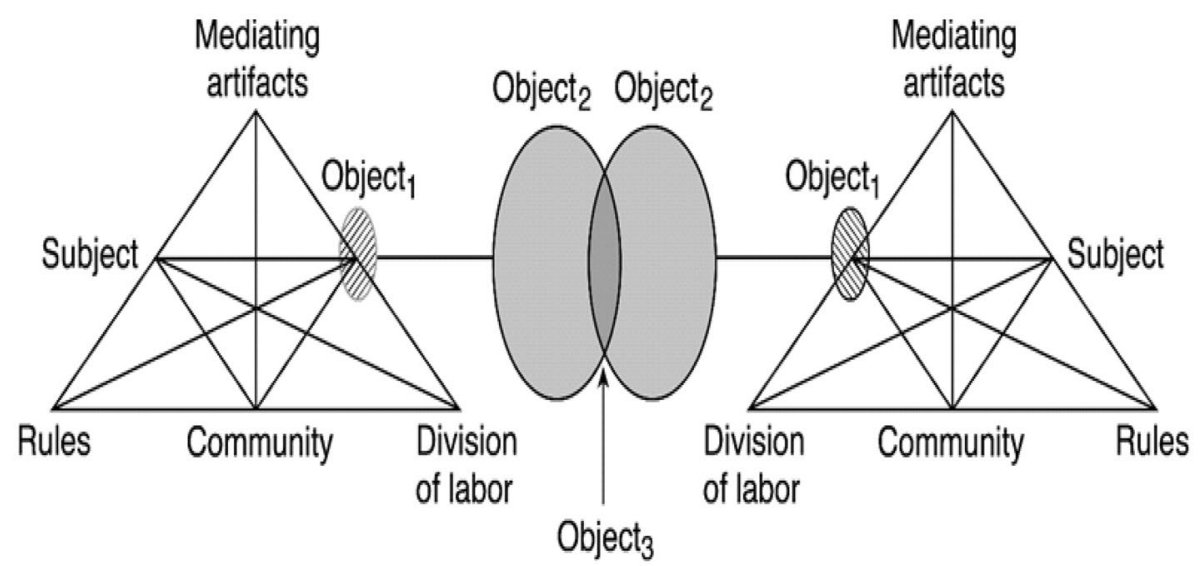

Fig. 3 Two interacting activity systems with a partially shared object adapted from Engeström (2001) 
individual activities. These chain reactions from the joint activities can lead to inner contradictions for the individual activity and the joint activity" (p. 509).

The concept of "object" is a complex notion in the context of activity theory and deserves elaboration, as having a precise understanding of the terminology is germane to this study. The notion of object is a central, but frequently misunderstood, element of activity theory (Foot, 2002). In activity theory, the object is the "problem area" to which the activity is directed. Kaptelinin (2005) elaborates on the key concepts of the object:

The object of activity can be considered the "ultimate reason" behind various behaviors of individuals, groups, or organizations. In other words, the object of activity can be defined as "the sense-maker," which gives meaning to and determines values of various entities and phenomena. Identifying the object of activity and its development over time can serve as a basis for reaching a deeper and more structured understanding of otherwise fragmented pieces of evidence. (p. 5)

The object of activity is ever-evolving, and the process of object-formation is neither linear nor universally experienced by those in a given activity system. Rather, as Foot (2002) writes, "at any point in time, participants in an activity may be at different stages in the contingent processes of need-consciousness and object-formation, thus shaping their ability to perceive and articulate the object of the activity in which they are engaged" (p. 8). When two or more activity systems interact, the object-formation process can become more complicated. And the difference in the respective objects of each activity system can increase tension between the interacting organizations (Engeström \& Sannino, 2010).

Tensions and Contradictions. Activity theory is a dialectical theory (Engeström \& Sannino, 2010). As Roth and Lee (2007) explain, all dialectical units, including activity systems, "harbor inner contradictions" (p. 203). Contradictions emerge and evolve within any human activity, and are the driving force of transformation (Engeström, 1987). Engeström and Sannino (2010) elaborate on the role of contradictions in human activity, noting that "the object of an activity is always internally contradictory. It is these internal contradictions that make the object a moving, motivating and future-generating target" (p. 5). As Ilyenkov (1977) writes, "any concrete developing system includes contradictions as the principle of its self-movement and as the form in which the development is cast" (p. 330). Thus, contradictions are not only inescapable; they are necessary for development and transformation of activity. When activity members encounter contradictions and engage in a process of resolution, the activity has the potential to expand. Foot (2001) expands on the benefits of contradictions, and describes how they foster growth,

Contradictions are a sign of richness in the activity system, not weakness, and of mobility and the capacity of an activity to develop rather than function in a fixed and static mode. Contradictions reveal the growing edges of the activity system-the places where "growth buds" are able to form and where expansive development takes place. (p. 63)

Foot adds that contradictions are not "points of failure or deficits" and warns against viewing contradictions as problems waiting to be fixed, noting that easy-fix attempts might result in the "aggravation of existing contradictions or the emergence of new ones." To this end, solving contradictions is neither linear nor permanent. Rather, contradictions exist latently throughout the learning cycle (Toiviainen, 2007) and allow the researcher to study the "development of the individuals in the context of their activities as well as the development of collective activities" (Jóhannsdóttir, 2010, p. 169). 
Engeström (1987) presents four layers or levels of contradictions which relate to one another as activity systems develop and evolve. The four levels are summarized as follows,

level 1: primary inner contradiction within each constituent component of the central activity; level 2: secondary contradictions between the constituents of the central activity; level 3: tertiary contradiction between the object/motive of the dominant form of the central activity and the object/motive of a culturally more advanced form of the central activity; and level 4: quarternary contradictions between the central activity and its neighbor activities. (p. 71)

Engeström (1987) formulates the basic internal contradiction of human activity as its "dual existence as the total societal production and as one specific production among many" (p. 66). Engeström (2001) further situates the concept of contradictions in activity theory as follows, "the primary contradiction of activities within capitalism is that between the use and exchange value of commodities. This primary contradiction pervades all elements of our activity systems" (p. 137). As Foot and Groleau (2011) put forth, the primary contradiction is manifested in "tensions that arise from the dual construction of everything and everyone as both having inherent worth and being a commodity within market-based socioeconomic relations" (p. 5). While the primary contradiction is the foundational, ubiquitous driver of activity development, the generative force of contradictions is best understood when the four layers of contradictions are engaged. This is because the four different layers of contradictions are not isolated events, but rather, "precipitate one another, provoke distinct epistemic actions from different sets of organizational actors, and catalyze the development of organizing processes" (Foot \& Groleau, 2011, p. 1). As such, the understanding that tensions and contradictions within and across activity system elements are the motivating forces for change and innovation in practice is central to activity theory (Engeström, 2005a, b; Engeström \& Miettinen, 1999; Foot, 2001; Jóhannsdóttir, 2010).

Yet, while terms such as tensions, problems or conflicts are related to contradictions, in activity theory terms, the notion of "contradictions" is unique. Engeström (2001) explains the distinction, "contradictions are not the same as problems or conflicts. Contradictions are historically accumulating structural tensions within and between activity systems" (p. 137). Moreover, contradictions are not the same as experiential tensions.

However, while contradictions are inevitable to occur, Engeström (1999c) notes that they are not inevitable to be seen, "contradictions do not manifest themselves directly. They manifest themselves through disturbances, ruptures and small unremarkable innovations in practitioners' everyday work actions. The challenge is to make these disturbances and innovations visible and analyzable to practitioners and researchers" (p. 68). If tensions and disturbances are ignored or not recognized as opportunities for learning, expansion is stymied. Sannino and Engeström (2018) return to this notion when they write about contradictions as a foundational philosophical concept,

Inner contradictions need to be creatively and often painfully resolved by working out a new "thirdness," something qualitatively different from a mere combination or compromise between two competing forces. As contradictions are historically emergent and systemic phenomena, in empirical studies we have no direct access to them. Contradictions must therefore be approached through their manifestations. We may also treat manifestations as constructions or articulations of contradictions. In other words, contradictions do not speak for themselves, they become recognized when practitioners articulate and construct them in words and actions. (p. 49) 
Thus, the theoretical construct of contradiction is complex and cannot be elided with perceived tensions. Rather, contradictions are systemic. They shift the tectonic plates of activity and induce change. As Kuutti (1996) writes, "contradictions manifest themselves as problems, ruptures, breakdowns, clashes" (p.16), and provide opportunities for attempts to innovatively change the activity.

\section{Research Design and Method}

This study generates hypotheses on how the organization of a teacher education program affects the school partnership and the learning to teach process. The study is not intended to be a program evaluation. Rather, the purpose is to better understand the ways in which organizational characteristics of teacher education programs and school systems affect the collaborative work of preparing teachers.

The following two research questions guided my investigation:

1. How is the university-school relationship conceptualized and enacted in the teacher education program of focus?

2. How do organizational policies, practices and characteristics afford or constrain opportunities to develop the university-school relationship in teacher education?

Given the focus of my research questions, systematic qualitative methodology (Stake, 2006) was most useful for this study. Maxwell (2012) notes that qualitative methodology allows the researcher to gather rich and in-depth data about respondents' experiences which leads to a meaningful "understanding [of] the particular context within which the participants act, and the influence that this context has on their actions" (p. 22).

\section{Site and Participants}

This research examined a case of partnership between an elementary teacher education program and an elementary school. A case is defined as a clear and bounded system (Creswell, 1998; Merriam, 2009). Cases can be an instructional program, an activity, an institution, or an individual. In this study, the case is made up of an Elementary Teacher Preparation Program (ETPP) and a partner elementary school. The two organizations have a shared ecology (Ragin \& Amoroso, 2010), as they are associated with the same large public university on the west coast of the US. Additionally, the ETPP represents an example of the leading model for teacher preparation in the US. It is important to note that this program is not meant to portray a definitive archetype, as research demonstrates that there is great variation in program features and outcomes both within a given type of preparation program and across program models (Boyd et al., 2006; Gansle et al., 2012; Zeichner \& Conklin, 2005). Rather, the program serves as an instance of dominant model for teacher preparation.

The partner school, also referred to as field placement site, was selected using purposeful sampling (Creswell, 1998), with the following criteria: (1) the site was a public elementary school in a large urban school district, and (2) the school-program partnership was well developed and functioning in the ways implied by the program model. These criteria were driven by my research agenda and questions. This investigation could have focused on the genesis or dissolution process of partnerships or could have examined a defective 
partnership. While those lines of inquiry are worthy of exploration, they were outside of the research scope for this study. Volunteer participants, including representatives from the teacher education program, university, school district and partner school were recruited for a total of $17(n=17)$ study participants.

\section{Data Sources}

To ensure case study validity, multiple sources of evidence were sought (Merriam, 2009). In total, the data included the following: audio recordings and transcriptions of participant interviews; artifacts and documents from the involved organizations; and informal observations of program meetings. The collection of multiple sources of data increased the validity of each case study (Yin, 2008) and resulted in a rich evidentiary database to conduct data analysis to answer my research questions. Interviews were conducted using semi-structured interview protocols (Merriam, 2009; Patton, 1990, 2002), and data from participant interviews, organization artifacts and documents, and observations of meetings were triangulated through repetitious data gathering and critical review (Stake, 2006). The research was conducted in compliance with ethical standards and institutional review board approval. The names of programs, schools, and participants are pseudonyms. Table 1 summarizes the data collection methodologies.

\section{Data Analysis}

In determining the unit of analysis, this study drew on Sannino and Engeström (2018) who write, "the formation of minimally two activity systems connected by a partially shared object may be regarded as the prime unit of analysis for 3rd generation activity theory" (p. 46). To this end, the unit of analysis in this case was the partnership between organizations. The data analysis was informed by Miles and Huberman (1994), who suggest that analyzing data becomes an iterative process whereby the researcher uses analysis of initial data to inform a second round of data collection. Miles and Huberman (1994) continue in advising that "coding is analysis" where codes are used to "retrieve and organize words, phrases, sentences, or whole paragraphs, connected to unconnected to a specific setting" (p. 57). Throughout the analysis, data from interviews, field notes and artifacts were cross referenced to generate interpretations (Merriam, 2009; Yin, 2008). Next, I generated categories or themes in the data. This was an iterative process, during which I went back to my data, considered provisional categories, and revised my emergent themes to best represent the data. Ultimately, these analytic categories were used to identify data-represented themes.

\section{Ethical Considerations}

All the participants, instructors, and organizations were given pseudonyms to protect the identities of individuals. I openly communicated the purpose of my study to my participants. Continued participation in this study was voluntary. 


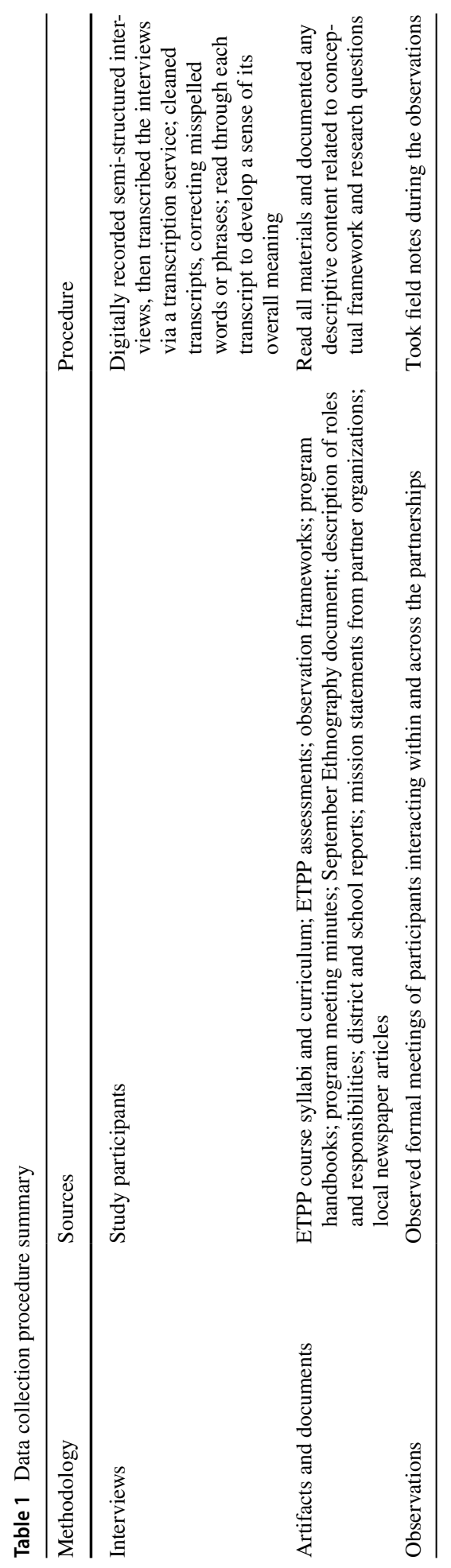




\section{The Elementary Teacher Preparation Program Overview}

The ETPP conceptualization of teacher education is driven by and organized around the goal of "collaboratively transforming inequitable institutional practices" (Program Handbook, 2018, p. 9). Additionally, as stated in the Program Handbook (2018), the ETPP vision for teacher education situates the process of learning to teach in the "school, community and greater socio-political environment" and focuses on "generous, deliberative, participatory on-going conversations that acknowledge and honor the multiplicity of expertise across boundaries" (p. 9). In activity theory terms, the subject represents the chosen position and point of view for the perspective of the analysis (Sannino \& Engeström, 2018). The subject for the university activity system analysis, in the context of participating in the ETPP partnership, is the collective of teacher educators, including university faculty, instructors, staff, and administrators. The collective of university teacher educators is driven by the shared motive of preparing teachers. This motive is embedded in the object of the activity. In other words, the object directing the university activity is the teacher candidate and their ongoing preparation. The teacher candidate can be understood as a project under construction, "moving from potential 'raw material' to a meaningful shape and to a result or an outcome" (Engeström, 1999c, p. 65). The object guides activity goals and actions, yet the object itself is ever evolving.

Activity theory highlights the collective aspect of human activity. As Sannino and Engeström (2018) note, "an activity system is more than a mechanical sum of its components. An activity weaves together its own dynamic context" (p. 46). To this end, the object gives meaning to the teacher education activity and motivates all of the activity system's elements. For example, the individuals and subgroups involved in the activity and who share the same general object are considered members of the university community. The ETPP community includes those directly involved in the teacher preparation process like, professors, teaching assistants, instructional coaches, and others who share an orientation to and engagement with the object, like faculty and deans. In acting toward the object, members draw on mediating artifacts, individuals, and instruments, known as tools, which help achieve the object-oriented activity of preparing teachers. The interconnectedness between the elements of the university activity system is illustrated by the role of formal and informal regulations and norms, or rules, that constrain actions within the activity. For example, university courses are regulated by the rule of practice-based instruction, in which "instructors strategically attempt to connect academic and schoolbased expertise" (Zeichner et al., 2015, p. 126). The convention of structuring coursework around a practice-based model for teacher education (Windschitl et al., 2011) is influenced by the shared community value of linking theory with practice. Similarly, the value of teaching for social justice held by the university community informs the rules of increasing cohorts of diverse teachers and partnering with social justice-oriented schools. Rules also influence the tools in the activity as seen in the structure of the coursework and field work, which are constrained by policies on course credits and hours in the field.

Lastly, the division of labor element captures how tasks and power are shared in the activity. For example, the literacy and numeracy methods courses are typically taught by tenure-line faculty and tenured professors while foundations courses are typically taught by clinical (non-tenure line) faculty, staff, and teaching associates. The structure of task and power distribution in the program is informed by the university rules and has implications for the ETPP partnership. For example, the Faculty Code lists members of the university in order, for purposes of determining voting eligibility based on superior rank, with professors 
near the top of the rank ladder, teaching associates at the bottom, and teaching assistants restricted from the list. In the ETPP context, tenured faculty, such as methods course professors, are placed at the locus of decision-making for the program. Figure 4 illustrates a full graphic summary of Engeström's (1987) model, showing the object-oriented activity of teacher preparation.

\section{The Partner School Overview}

One of the partner schools that serves as a member of the ETPP collective is Lincoln Elementary School. The partner school in this case is part of the Baldwin school district. The public-school district has shown uninterrupted growth since 2004, with over 20,000 students enrolled in 2018, with about 2000 employees, including about 1100 teachers. About one in five students in the district receives free or reduced-price meals. Ava Jackson, the district's Director of Employee Relations, described the evolving landscape of the district and the district's goals for meeting the needs of the students:

Tools:

Teacher education conceptual framework

Program meetings

Practice-based methods courses

Additional courses and caucusing

September ethnographic experience

Field-based experience and support

Mentor teacher matching and field placement selection process

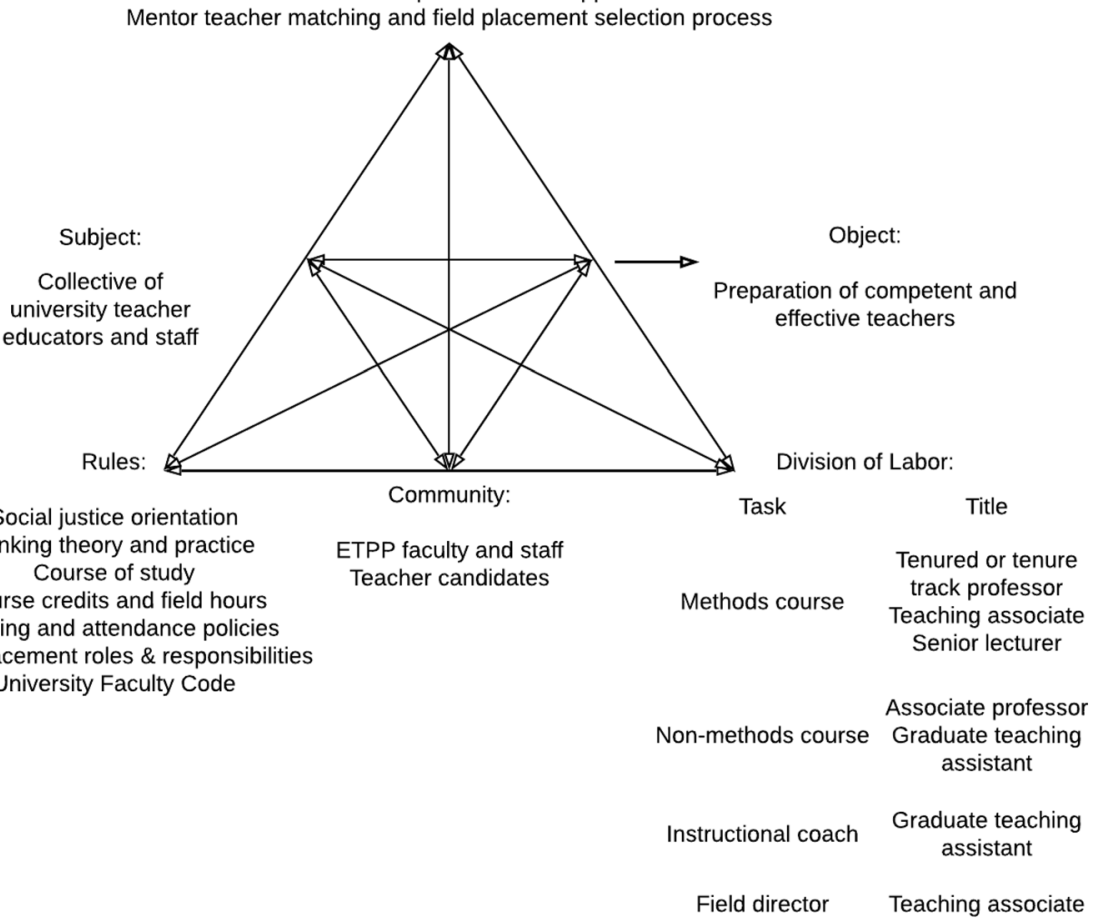

Fig. 4. The university activity system in ETPP 
I would say that our diversity is growing and changing in our district, and one of our goals and commitments is to diversify our staff as well to be able to relate and to connect with our families and with our students. We're still in the $80^{\text {th }}$ percentile of white teachers, yet we are $80 \%$ non-white students. So there's a disconnect. So we have to work vigilantly, passionately, and have a commitment to diversify our staff. (A. Jackson, personal communication, November 21, 2018)

Lincoln elementary is a kindergarten through fifth grade, Spanish Dual Language, Title I school serving approximately 400 students. Deborah Olivier is in her fifth year as the principal of Lincoln, and shared the overview of the school:

We have about 430 students. In kindergarten through second grade, $90 \%$ of the instruction is in Spanish and 10\% in English. Then, third through fifth grade, it's 50/50. Lincoln also has a functioning life skills center based special education program, that is also K-5. (D. Olivier, personal communication, November 19, 2018)

According to a summary from the school's three-year improvement plan, "the school staff encourage a college bound culture and are committed to an unwavering belief that each student is capable of learning at high rates." Principal Olivier elaborated on school's main tenets and explained what she means by teaching for social justice. In her words,

We have an inclusive approach, these are all our students, and we take a strengthbased perspective. We value linguistic diversity and what are our kids are bringing. This school values multilingualism and this school elevates languages other than English. And it's not in an "oh English is not important" way, it's English isn't the only important language. (D. Olivier, personal communication, November 19, 2018)

During one of my visits to Lincoln elementary, I witnessed what seemed like an aspect of this idea enacted by the school community. I arrived a few minutes before the start of the meeting I was slated to observe and caught the start of a fourth-grade class. I observed students standing with their hands on their chests, facing an American flag. Over the loudspeaker I heard a student's voice announce, "now, the pledge of allegiance," and listened as the students recited the pledge from memory, first in Spanish, then once more in English.

The school's vision includes collaborating with students, families, staff, and the community to meet the needs of every student and is guided by a commitment to teaching for social justice. In activity theory terms, this vision represents the motive for the Lincoln Elementary School activity and is embedded in the object of the activity. According to document and interview data, the main object directing the school's activity are the K-5 students and their ongoing learning. The individuals acting on the object, for example the teachers, specialists and school administrators are considered the subject for the Lincoln elementary school activity system analysis. Similar to the university object described in the preceding section, the subject is given meaning by the ever-changing school object as manifested in countless intermediate goals. For example, according to the data, the math specific goals for second-grade include the following: "(1) extending understanding of base-ten notation; (2) building fluency with addition and subtraction; (3) using standard units of measure; and (4) describing and analyzing shapes." These goals are further broken down by the second-grade teachers and constantly reconstructed under the guidance of the object.

The community members of Lincoln school activity include district leadership, school administration, general and special education teachers, support staff, specialists, students, and families. Members of the community use various tools such as 
curricula resources, including the district-wide math curriculum, lesson plans, and classroom materials shape the activity and mediate the subject acting on the object of meeting the needs of students. For instance, the elementary literacy curriculum draws on materials from the school-wide "Journeys" reading curriculum program and the math program in the school follows the district-wide curriculum called "Math Expressions Common Core." The school's division of labor organizes the daily school activities among members such as school administrators, teachers, specialists, and support staff. Finally, the Lincoln school activity is regulated by rules, for instance state and district benchmarks for student achievement which help guide instructional decisions. Other rules are shaped by the community element, for example, the value of linguistic diversity held by the community is reflected in the school's dual language program, a rule that guides the activity. The activity's interactive nature is additionally surfaced in the division of labor element, as the rule of Spanish dual-language instruction requires the task-distribution of teaching in Spanish and English. Figure 5 provides a full graphic summary of the partner school using Engeström's (1987) model, with the school activity oriented toward the object. The activity is mediated by the interactive elements of the activity system, indicated by the two-headed arrows between nodes.

Tools:

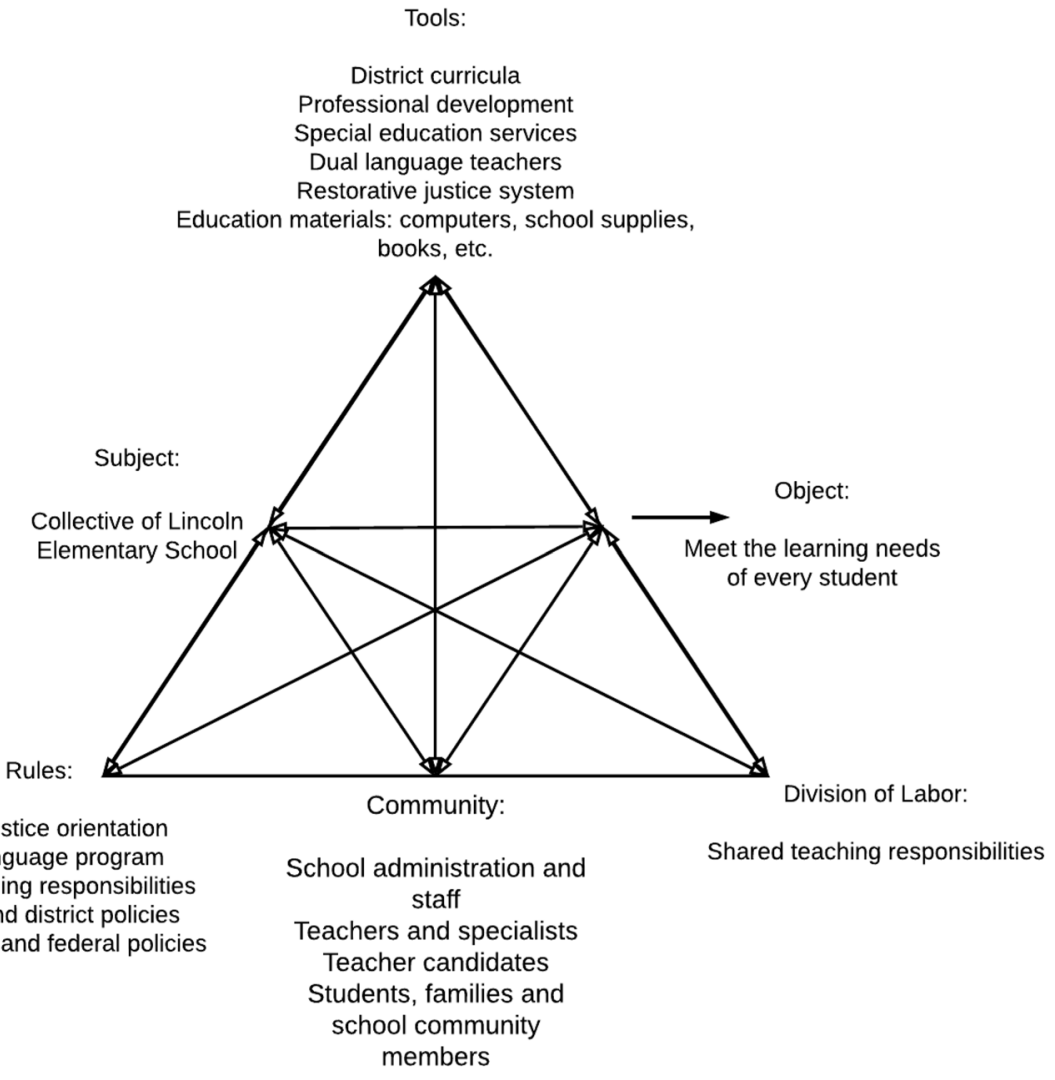

Fig. 5 The Lincoln elementary school activity system 


\section{Findings}

In the previous sections, I presented the two organizations involved in the collective ETPP activity, embedded within their respective real-world contexts, and shared examples of the interrelationships between the elements within each system. The results of these analyses allowed me to identify the goals and the complex natures of both systems. Building on these analyses, I return to the unit of analysis in this case and consider the joint activity of preparing teachers that is shared across the organizations. To this end, I shift my analytic focus from the separate systems to the relationship between them and draw out systemic implications. In doing so, I turn to Engeström (1987) and Rogoff (1995) who explain that the unit of analysis is the human activity itself, embedded within its social context. As Yamagata-Lynch (2010) explains, "[in activity theory], this unit of analysis embraces the belief that real-world activities cannot be isolated into variables" (p. 6).

In reviewing the descriptive data from the university and partner school activity systems, I identified two central themes pertaining to the university-school relationship in the ETPP case. First, the presence of multiple and at times competing motives, priorities, and objects led to tensions between the two activity systems; and second, organizational structures within and across activity systems afforded and constrained how the partnership engaged the found tensions.

\section{Multiple Objects}

As members navigated between the two activity systems, they encountered the challenge of engaging multiple objects. For instance, as depicted in Fig. 5, members of the Lincoln school activity system, including mentor teachers, were oriented toward, and organized by, the object of teaching K-5 students. In fact, the primary way teachers, including cooperating teachers, serve their profession is by acting toward the object. By being elementary school teachers to elementary school students. Taking on the role of mentor teacher neither supplanted their role of teacher nor replaced the object of teaching K-5 students. Mentor teachers were still regulated by the rules of the school and drew on tools in the school activity system for resources as they acted on the object. Yet, by partnering with teacher candidates, cooperating teachers also became active participants in the collective activity of preparing teachers.

In discussing their approach for acting toward the school object while participating in the university object, mentor teachers noted the importance of "flexibility." Ms. Washington described creating moments for teacher candidates to practice their teaching, even when it is not in line with the school curriculum,

I know that when they [teacher candidates] get further in their course work, that there might be some lessons they have to teach or something that may or may not particularly fit with our literacy curriculum or our science curriculum. And we're very flexible at our school. I'm very flexible. If the lesson, it doesn't necessarily fit in, if it's still important, let's do it. (M. Washington, personal communication, November 29, 2018)

While Ms. Washington's generous flexibility provided some relief for engaging the two objects, it also raises some questions. For instance, how many non-curriculum lessons can be taught without causing disturbance in the Lincoln curriculum rule? And do isolated opportunities for enacting coursework concepts support the object of learning 
to teach? Emerging answers to these questions appeared in the data and suggest constraints to the ad hoc "fit it in" approach, as seen in this teacher candidate's discussion on navigating the two activities,

[The] kind of math instruction [presented in math methods], I'm not always seeing it in my placement. And, in my placement, I feel like it's very much geared towards working out of a textbook from the districts. Then, again, as I said, I wanted to try out [an activity] and [the cooperating teacher] was like, "Sure, go ahead." So, I think she's open to things, but I understand too that they're adhering to different pacing guides and trying to meet different marks, and so, yeah... So sometimes, what we're seeing in our methods courses, those are cool things I think I'm thinking about, okay, for my future class, or when I can take over a little bit more and get creative, right? (E. Choi, personal communication, November 9, 2018)

This quote provides an example of a conflict between objects. The object of preparing teachers, assisted by tools such as specific activities for teaching math is in conflict with the Lincoln object of teaching students, assisted by tools such as district math curriculum. A similar conflict appeared in literacy instruction, "in our methods course, there's a lot of focus on taking a deep dive into non-fiction text. We're not really doing that all too much in a first grade class right now" (E. Choi, personal communication, November 9, 2018). In this moment of partnership, the focus of reading non-fiction text is incompatible with the focus of Lincoln's first-grade classroom.

Additionally, some members grappled over the value of one object versus another, suggesting that at times the objects were understood as separate and perhaps competing concepts. For example, the primary object orienting the activity of teacher candidates was learning to teach. However, during their field work, candidates were also becoming members of the Lincoln school community and gaining exposure to the school activity system. As emerging members of the Lincoln system, the activity of teacher candidates became additionally organized by the school's object of teaching students. As candidates navigated between acting in a teacher preparation program and acting in a partner school, they began viewing the school object as more "real," as seen in an interview in November, 2018 with teacher candidate Erica:

BK Where do you think you've learned so far, maybe not the most, but a lot, in the various different components of the program?

EC I feel like the moments where we're having that practical hands-on experience of actually being out there and teaching students is the most valuable and the most true-to-form... because you can plan a lesson all you want, but that's only half of the planning. The other part is the student voice in that. And so, I find it very interesting to be in those real-life situations, where it's like, "how this person is responding?" or "I tried out this strategy, and it didn't quite go like how I read about it in the book." So that's been a great wealth of learning. Not to discredit the learning that goes on in our methods or our coursework in general. That is definitely supportive and getting to bounce ideas off of different instructors has been good, but, yeah, like actually getting out there, and kinda seeing what it feels like for real, is a great learning experience. (E. Choi, personal communication, November 9, 2018)

Here, Erica grappled with squaring the value of orienting her activity toward real students in the Lincoln system with the value of orienting her activity toward discussing coursework as a tool for learning to teach. Teacher candidate Lori shared similar concerns about he friction between the two objects, 
You can talk about concepts all you want, but you're not gonna actually understand what happens in a day-to-day classroom unless you actually experience it. We can read all the articles we want, but that's not gonna compare to actual real-life experience. (L. Battaglia, personal communication, November 9, 2018)

While candidates stopped well short of considering the objects within the ETPP collective activity as incompatible, they struggled in holding both objects simultaneously.

In activity theory terms, these tensions can be described as intertwined dilemmas, or "expressions or exchanges of incompatible evaluations, either between people or within the discourse of a single person" (Engeström \& Sannino, 2011, p. 373). On the one hand, the placement school is an essential component in the object of preparing teachers, as it allows teacher candidates to practice their teaching; on the other hand, the placement school activity is oriented toward its own object of teaching students. Similarly, on the one hand, university coursework helps drive the activity toward the object of learning to teach; on the other hand, working in the placement school partially reorients the activity to the more pressing object of teaching students. The misalignment or opposition of intermediate goals between activities, as determined by the objects, led to dilemmatic moments in the partnership.

\section{Scant Opportunities for Collaboration}

As evidenced by the data, two roles that were closely involved in the process of preparing new teachers were course instructors and cooperating teachers. Both members worked tirelessly to help develop teachers for the classroom, and each spent the greatest number of hours with the candidates. Teacher candidates worked with methods instructors, learning content and theory in courses, and with cooperating teachers, honing their craft and developing their practice in classrooms. However, data suggested that collaboration between methods instructors and their courses and cooperating teachers and their classrooms was restricted. This issue was exemplified in a reflection by the Lincoln school site supervisor and cooperating teacher, prompted by my question: "have you had any conversations with methods instructors?",

No, I've never, I've not had that. But, that would be something I think, as an option, would be nice... Wouldn't it be nice too, if a mentor teacher could shoot a line to a professor about "here's something really awesome she [teacher candidate] has done" and to be able to celebrate that together? (J. Burkett, personal communication, November 29, 2018)

Ms. Burkett continued by listing the potential benefits of having a closer her relationship with the university faculty,

Being able to maybe share or find out who the professors are, and if we have a question, being able to reach out to someone who can maybe support [teacher candidates] outside of the time that they're here, that might be good. (J. Burkett, personal communication, November 29, 2018)

Similarly, mentor teacher Ms. Washington pointed to having more information on the methods coursework to improve the student teaching experience,

I know that if we got that schedule, of what the student-teacher's, kind of their timeline, I think it would be interesting. And I know maybe this changes year from 
year, but if we could kind of know ahead of time what are some of the lessons they [teacher candidate] know they have to teach, to kind of know some more of that content piece so we could start to plan that ahead of time... Like in the fall and it could say, "during the fall, here are some of the assignments they need to have completed", and I'd have a reference point. Or, if I know she [teacher candidate] needs to do an assignment where she works with an ELL student, to be like, "Okay, I can start thinking about that ahead of time, like who is a good student?" (M. Washington, personal communication, November 29, 2018)

However, when asked about her connection and relationship with the mentor teachers or principals at the placement schools, Professor Morgan replied, "it doesn't exist... I don't know, because I'm barely involved in placements, barely." Professor Charun also noted that she does not interact with mentor teachers and discussed this issue during a December 2018 interview:

BK How do you think about field placements and what teacher candidates are doing in schools?

JC I think, this is something we really need to get better at if we want to think about systems of teacher preparation or systems of teacher professional learning, of which teacher prep is something, and then in-service [teachers] is also part of that same group. Because honestly, I have no idea what's going on [in field placement].

BK And, any connection with the principals of the partner schools?

JC I haven't had any. (J. Charun, personal communication, December 10, 2018)

Literacy and numeracy methods instructors shared concerns over the missing link to the mentor teachers and noted that capacity and logistics were obstacles in creating and sustaining relationships with partner schools. For example, the rules regulating the coursework activity require a practice-based approach to methods instruction. As such, methods instructors spent much of their time commuting between home, the university, and the offcampus elementary schools where they held methods courses. Additionally, as tenure-line faculty, expectations for methods instructors extended to university-specific activities such as engaging in research and publishing in line with a top tier university. Taken together, Professors Charun and Morgan wondered whether building relationships with partner schools and mentor teachers was possible under the current organizational structure. The impacts of restricted collaboration seemed to exacerbate the dilemma of competing goals. This issue was showcased by Ms. Thompson's reflection on areas for growth in her role as a mentor teacher, as she grappled with better aligning her teaching practice to the methods coursework while staying true to "real life,"

Maybe I'm not connected enough to what's going on in their coursework, even just knowing what courses they're in... but this is the real world. Like really, sometimes I'm planning this little lesson five minutes before they [first grade students] come in the door, real life. Or oh, somebody puked and we're not doing this and now what are we gonna do? And so, yeah, I mean you probably can't plan for that in your methods class. (B. Thompson, personal communication, November 26, 2018)

The quote from Ms. Thompson not only echoed the problem of limited collaboration between mentor teachers and methods instructors; it also suggested a connection to the previous theme of competing goals. That is, Ms. Thompson's activity was oriented 
toward the object of teaching Lincoln elementary school students. This object is everchanging and Ms. Thompson must be flexible and responsive to the evolving needs of her students. When the university object was introduced to the Lincoln activity, Ms. Thompson experienced a contradiction between the K-5 student-centered school object and the perceived student-decentered university object. This led Ms. Thompson to assume that methods courses could not account for the constantly changing setting of a first-grade classroom. Due to the constraints for collaboration, it was as unknowable to Ms. Thompson whether her assumption was accurate as the assumption itself was unknowable to the methods instructors.

Instructional Coach Support. The tasks pertinent to engaging and collaborating with community members in the partner school activity system, including crossing organizational boundaries and linking the two system, were primarily divided among the instructional coaches according to the university rules. Professor Charun reflected on this structure,

I think as a program... I think we just have to keep working on it, on how do we make it so that we are a system of teacher educators who are working, and thinking, and getting smarter together? As opposed to, "you're a mentor teacher. You are responsible for what happens there. I am a coach, and I'm sort of this bridge...”. I wonder how the coach is kind of torn between different things, and then the people that teach methods are over here somewhere. So, I do think that's something that we can keep working on, and hopefully learn from. (J. Charun, personal communication, December 10, 2018)

Professor Morgan also discussed the complex role of the instructional coach,

It has potential, but I think Elementary is particularly difficult. We're preparing teachers to teach all subject areas, plus attend to needs of kids, which are part of the subject area, but I mean classroom management and cultural linguistic diversity and all the things that are part and parcel of teaching. Plus, there's a responsibility for teaching across subject areas. So, I am not going to be a good coach in mathematics. I am not going to be a particularly good coach or teacher educator in social studies. I don't have the expertise. So, what you have, the bridges are generic bridges, and [research shows] generic bridges lead to conversations about classroom management. I think it's a mistake... If my first eye is on classroom management because I don't know enough about the subject matter, then you get advice about fixing the wrong problem. I think that those bridges are content weak, and I am just unyielding about content knowledge. (S. Morgan, personal communication, December 12, 2018)

Instructional coach Caleb worried that his dearth of knowledge and experience around literacy constrains his effectiveness as a coach. He explained that being the teaching assistant for numeracy methods enables him to be confident in his role as the instructional coach, but his confidence wanes on literacy content,

I haven't worked with Professor Morgan. I'm not exactly sure what they're doing, and I also don't wanna contradict what she's doing, so whenever [teacher candidates] let me know that like, "hey, I wanna try a read aloud or I wanna try this new strategy that we've been working on literacy", I always let them know, it's like, 
"yeah, great! Let's do it," and sort of ask them what they want me to be looking for. So, instead of just for me to provide them with all this feedback, I ask them, "Is there something in particular that you want me to focus on? Is there something that you want feedback on, specifically?", that sort of guides our conversation. (C.

Richardson, personal communication, November 15, 2018)

These interview data surfaced another dimension of the friction around collaboration. In addition to minimal interaction across systems, between methods instructors, mentor teachers and their respective tasks, internal collaboration between coaches and methods instructors was inhibited. The university division of labor indicated that the instructional coach was responsible for supporting candidates across contents and disciplines in the field, yet systems for communication between instructors and coaches were absent. For instance, methods instructors did not participate in the coaching team meetings, and while instructors and coaches were present for program-wide meetings, explicit and dedicated collaboration between these two roles was not observed.

The conditions of the interaction between the two activity systems brought forth several related tensions, as depicted in Fig. 6 with a full graphic summary of Engeström's (2001) model for two interacting activity systems. The multiple and at times competing goals of the university and Lincoln school systems introduced a cross-system dilemma (a) between the objects of the two activity systems, depicted with the help of a twoheaded lightning-shaped arrow between the objects of the two activity systems. The constrained collaboration between methods instructors and cooperating teachers produced a cross-system tension (b). Tension (b) is represented as a two-headed lightningshaped arrow between the divisions of labor of the two activity systems. The limited collaboration between methods instructors and coaches created an internal tension (c) in the university system, shown as a two-headed lightning-shaped arrow between the division of labor and rules.

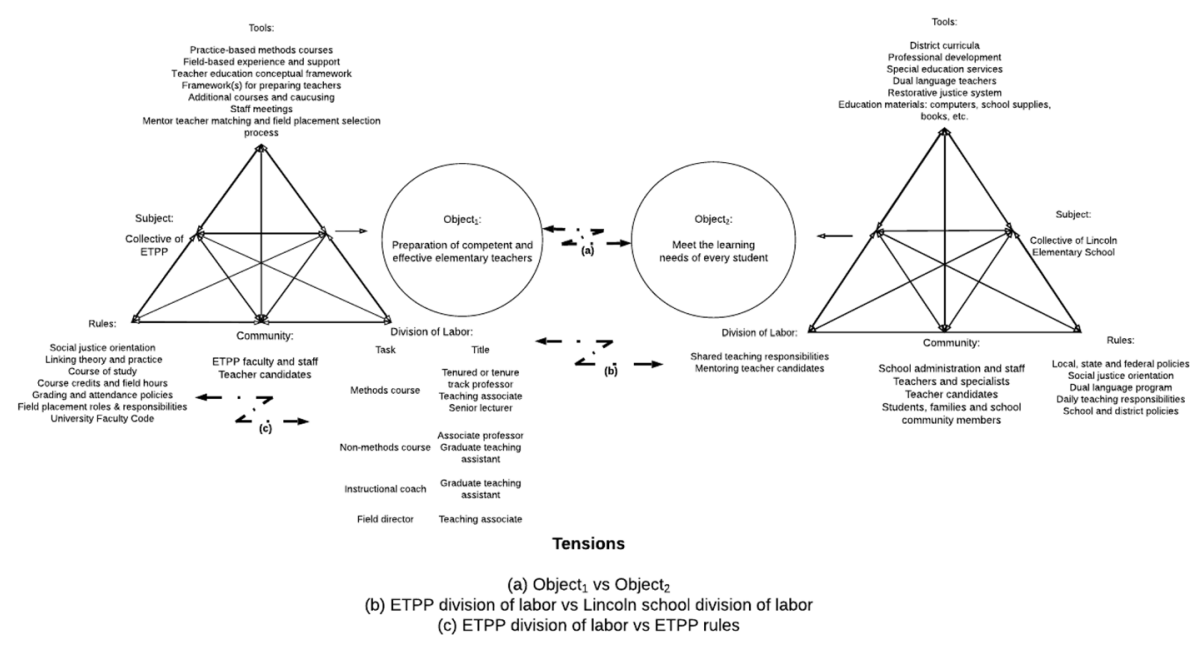

Fig. 6 The collective of ETPP partnerships 


\section{Discussion}

This study examined the university-school relationship in teacher education. More precisely, this study historically situated the problem of the university-school divide in teacher education and identified its manifestation in a year-long masters-level university-based teacher preparation program. The underlying motivation driving this research was to examine the old problem of the university-school divide in a new way by considering the endeavor of teacher preparation as a collective human activity and investigating the process as it developed across two systems, bound by the shared activity of preparing teachers. Two major findings were revealed in the data: first, multiple and at times competing motives, priorities, and objects produced tensions between the activity systems; and second, organizational structures within and across activity systems afforded and constrained how the partnership engaged the found tensions, informing the potential for expansive development. In the section to follow, I discuss the results from the study in relationship to extant scholarship and present the next steps for research in this area.

The first finding focused on the complex relationship between the university and the school, primarily in the context of teacher education. This finding was presented in two parts. First, the collective activities of the multi-system partnership were oriented toward the partially shared object of teacher candidates and their ongoing process of learning to teach. This finding relates to the literature on the university-school divide, which notes the mutual benefits of partnerships in teacher education, especially between teacher education programs and K-12 schools, and is supported by abundant evidence (e.g., Darling-Hammond, 2006, 2010; Valencia et al., 2009; Zeichner, 1996, 2010). Connecting theory with practice is recognized as a critical component in the learning to teach process (Grossman, 2010), and exposing preservice teachers to authentic school contexts so that they are better prepared for participating in the school activity after their training is a driving force for the universityschool partnership in teacher education (Darling-Hammond, 2006, 2010; Zeichner, 2010). Second, data revealed that the organizations involved in the partnerships were also oriented toward additional and at times diverging objects, which produced tensions and sometimes manifested contradictions. For example, the ultimate goal for the university partner in ETPP was to prepare elementary school teachers, while the ultimate goal for the school partner was to teach K-5 students.

Taken together, this finding contributes to the literature by underscoring that the "university" and "school" are two separate and central activity systems, oriented toward their own objects. Writ large, the university and school objects of activity are preparing teachers and teaching students, respectively. While object-oriented activities are complex, everevolving, and undoubtedly related to one another, data from this study suggest that the overlap between the two systems remains partial. That is, the goals of the two activities are related but not the same. Conceptually, the objects of the university and the school in teacher education might be imagined as two satellites orbiting a planet. The satellites share much of the same properties and experiences, and even share the same gravitational connection to the planet, but their orbits will always remain at a distance and their missions will be distinct. In a similar way, the university-school divide in teacher education might be considered as the distance between two similar yet different organizations, that share ideas, resources and goals while serving different purposes. Lincoln elementary school joined a teacher education program as partner schools and participated in the collective activity of preparing teachers. However, the school remained in its own orbit, guided by teaching students. Similarly, the ETPP coursework was developed to prepare new teachers in a 
way that would best benefit their future schools and students, yet the orbit of the programs from the university perspective was guided by the process of producing teachers. In this context, the gap between the university and school is a by-product of two or more organizations interacting while continuing to act toward their own priorities. This finding complicates the leading notion in teacher education which calls on embedding teacher preparation in the PK-12 school setting and centering clinical school-based practice in teacher education programs. Embedding teacher preparation in the PK-12 school system without first, or simultaneously, supporting universities and schools to engage in collaborative expansion of the object oriented activity of teaching and learning results in the unresolved contractions found in this study.

The second finding of this study demonstrated that organizational structures shaped how the partnership engaged in the perennial problem. Activity theory sees contradictions, manifested in everyday actions as dilemmas and conflicts, as the driving force of change and development (Engeström \& Sannino, 2011). Contradictions are inevitable features of collective activity and represent the possibility for motivating transformative change and development. However, while contradictions in collective activities are inevitable and have the power to bring forth development, contradictions cannot be presumed to make themselves known, and development is not guaranteed. If contradictions are not recognized, then the transformative power they offer will likely go unused. Wilson (2014) expands on this notion, "contradictions within activity systems may persist because they are not fully recognized. Using the CHAT framework for analysis enables researchers to identify these contradictions and to suggest possibilities for expansive learning as a result" (p. 23). In this context, the second finding shows that while contradictions, expressed as tensions, were found in the partnership, leveraging contradictions for transformative change was constrained by the organizational structures. For instance, conflicting moments arose between the foci of the university methods coursework and the school's teaching practice, such as the focus on non-fiction text in a course and the absence of this focus in a first-grade classroom. The resolution to these instances of conflict found in the ETPP partnership seemed to rely on stopgap measures and case-by-case solutions. Cooperating teachers resorted to flexibility in their teaching plans and offered to create spaces outside of their regular teaching for teacher candidates to make connections between the methods theory and classroom practice. The instructional coach in the ETPP partnership also attempted to ease tensions by providing general support in the field. However, the organizational structures of the partnership restricted interaction between methods instructors and Lincoln school cooperating teachers. Due to the restrictions, members significant to the object of preparing teachers across the involved communities were unable to engage in dialogue on the tensions that were surfacing in the activity. Consequently, the contradiction remained unrecognized and the opportunity to transform and expand the object was missed.

\section{Instead of Conclusions: Engaging the University-School Contradictions}

In her writing, cultural-historical psychology scholar Anna Stetsenko often concludes articles with the following heading: "Instead of Conclusions: [ ]". For example, Instead of Conclusion: Considering the Pitfalls of Anthropocentrism (Stetsenko, 2020) or Instead of conclusions: Agency and the Covid-19 pandemics (Stetsenko, 2020) or Instead of Conclusions: Sociopolitical implications (Stetsenko, 2019). Drawing on this 
approach, the final section in this article considers directions for future research on the university-school divide.

One promising avenue of expansion for this study is to further engage the contradictions framework. Specifically, activity theory provides a typology of four types of contradictions (primary, secondary, tertiary, and quarternary). Foot and Groleau (2011) write that the contradictions form a "sequence that explains the process of cyclical development characterized in CHAT" (p. 5). Furthermore, development of activity or system learning is brought forth by engaging in the contradictions and moving through an iterative cycle of triggering and resolving the contradictions. The process for creatively and collaboratively seeking to address contradictions is known as expansive learning (Engeström \& Sannino, 2010). Engeström (2007) describes expansive learning as referring to "processes in which an activity system, for example a work organization, resolves its pressing internal contradictions by constructing and implementing a qualitatively new way of functioning for itself" (p. 24). The purpose of the expansive learning theory is to consider the complex process of learning from the abstract to the concrete and explain and guide "collective transformation efforts in organizations and workplaces" (Engeström et al., 2013, p. 82). The analytic of expansive learning can be used as a framework for identifying and understanding contradiction-driven development in activity systems. Data from this study strongly suggest the presence of contradictions. However, conducting a contradictions analysis and considering the concept of expansive learning requires longitudinal data, the collection of which was beyond the scope of this study. To this end, while I engage in a generic discussion of contradictions, additional research would allow me to delineate the mechanisms of change over time and thoroughly analyze the levels of contradictions.

This qualitative inquiry sought to investigate the university-school relationship in teacher education from an organizational perspective. As seen in the findings, the teacher education program was oriented toward the object of preparing teachers, and the partner school was oriented toward the object of teaching and supporting students. Each organization was regulated by its own internal and external rules and had its own members and community set values, divisions of labor, and tools that helped act toward the object. Additionally, while organizational structures can enhance the relationship between teacher education programs and partner schools, data show that collaboration across organizations between members such as teacher educators, instructional coaches and mentor teachers is constrained by systemic directives, such as mandatory school district curricula and program-wide frameworks for teaching-and-learning. Although past initiatives rightly attempted to build systems for collaboration across organizations, they failed to address the diverging organizational goals. For example, the collaborative construction or alignment of K-12 and teacher education curricula between school district leadership, practicing teachers and teacher educators was absent from the Centers of Pedagogy and Professional Development Schools. The paucity of such robust collaboration likely resulted in unaddressed contradictions between organizations and hindered the learning to teach process. Just as individuals acting in collective practices or communities cannot be reduced to "sums of individual action" (Engeström \& Miettinen, 1999, p. 11), the university-school relationship in teacher education is not reducible to sums of individual action, it involves organizational and systemic structures. Simply put, organizational structures matter for teacher education. 


\section{Declarations}

Conflict of Interest The author declares no competing interests.

\section{References}

American Association of Colleges for Teacher Education. (2018). A pivot toward clinical practice, its lexicon, and the renewal of educator preparation: A report of the AACTE Clinical Practice Commission.

Bakhurst, D. (2009). Reflections on activity theory. Educational Review, 61(2), 197-210.

Ballantyne, J., \& Packer, J. (2004). Effectiveness of preservice music teacher education programs: Perceptions of early-career music teachers. Music Education Research, 6(3), 299-312.

Boyd, D. J., Grossman, P., Lankford, H., Loeb, S., Michelli, N. M., \& Wyckoff, J. (2006). Complex by Design Investigating Pathways Into Teaching in New York City Schools. Journal of Teacher Education, 57(2), 155-166.

Bullough Jr, R. V., Birrell, J. R., Young, J., Clark, D. C., Erickson, L., Earle, R. S., \& Egan, W. (1999). Paradise unrealized: Teacher educators and the costs and benefits of school/university partnerships. Journal of teacher education, 50(5), 381-390.

Cochran-Smith, M. (2008). The new teacher education in the United States: Direction forward. Teachers and Teaching: theory and practice, 14(4), 271-282.

Cole, M. (1996). Cultural psychology: A once and future discipline. Harvard University Press.

Cole, M., \& Engeström, Y. (1993). A cultural-historical approach to distributed cognition. In G. Salomon (Ed.), Distributed cognitions: Psychological and educational considerations. (pp. 1-46). Cambridge University Press.

Creswell, J. W. (1998). Qualitative inquiry and research design: Choosing among five traditions. Sage.

Darling-Hammond, L. (2006). Constructing 21st-century teacher education. Journal of teacher education, 57(3), 300-314.

Darling-Hammond, L. (2010). Teacher education and the American future. Journal of teacher education, 61(1-2), 35-47.

Daniels, H. (2004). Cultural historical activity theory and professional learning. International Journal of Disability, Development and Education, 51(2), 185-200.

Elementary Teacher Preparation Program (2018). Program Handbook.

Ellis, V., Edwards, A., \& Smagorinsky, P. (2010). Cultural-historical perspectives on teacher education and development: Learning teaching. Routledge.

Engeström, Y. (1987). Learning by expanding: An activity-theoretical approach to developmental research. Helsinki.

Engeström, Y.(1999a). Activity theory and individual and social transformation. In Y. Engeström, R. Miettinen, \& R. L. Punamäki-Gitai (Eds.), Perspectives on Activity Theory. (pp. 1-15). Cambridge University Press.

Engeström, Y. (1999b). Innovative learning in work teams: Analyzing cycles of knowledge creation in practice. In Engeström, Y., Miettinen, R., and Punamäki-Gitai, R.L. (Eds), Perspectives on Activity Theory. Cambridge: Cambridge University Press.

Engeström, Y. (1999c). Expansive visibilization of work: An activity-theoretical perspective. Computer Supported Cooperative Work (CSCW), 8(1-2), 63-93.

Engeström, Y. (2001). Expansive learning at work: Toward an activity theoretical reconceptualization. Journal of education and work, 14(1), 133-156.

Engeström, Y. (2005a). Developmental work research: Expanding activity theory in practice (Vol. 12). Lehmanns Media.

Engeström, Y. (2005b). Knotworking to create collaborative intentionality capital in fluid organizational fields. In Beyerlein, M. M., Beyerlein, S. T., \& Kennedy, F. A. (Eds.). Collaborative capital: Creating intangible value, (pp. 307-336). Emerald Group Publishing Limited.

Engeström, Y. (2007). Enriching the theory of expansive learning: Lessons from journeys toward coconfiguration. Mind, culture, and activity, 14(1-2), 23-39.

Engeström, Y., Miettinen, R., \& Punamäki, R. L. (1999a). Perspectives on activity theory. Cambridge University Press.

Engeström, Y. and Miettinen, R. (1999). Activity theory: A well-kept secret. In Engeström, Y., Miettinen, R., and Punamäki-Gitai, R.L. (Eds), Perspectives on Activity Theory. Cambridge: Cambridge University Press. 
Engeström, Y., Engeström, R., \& Vähäaho, T. (1999b). When the center does not hold: The importance of knotworking (Vol. 381).

Engeström, Y., \& Sannino, A. (2010). Studies of expansive learning: Foundations, findings and future challenges. Educational research review, 5(1), 1-24.

Engeström, Y., \& Sannino, A. (2011). Discursive manifestations of contradictions in organizational change efforts. Journal of Organizational Change Management, 24(3), 368-387.

Engeström, Y., Rantavuori, J., \& Kerosuo, H. (2013). Expansive learning in a library: Actions, cycles and deviations from instructional intentions. Vocations and Learning, 6(1), 81-106.

Feiman-Nemser, S., \& Buchman, M. (1985). Pitfalls of experience in teacher preparation. Teachers College Record, 87(1), 53-65.

Foot, K. A. (2001). Cultural-historical activity theory as practice theory: Illuminating the development of conflict-monitoring network. Communication Theory, 11(1), 56-83.

Foot, K. A. (2002). Pursuing an evolving object: A case study in object formation and identification. Mind, Culture, and Activity, 9(2), 132-149.

Foot, K., \& Groleau, C. (2011). Contradictions, transitions, and materiality in organizing processes: An activity theory perspective. First Monday, 16(6).

Fullan, M., Galluzzo, G., Morris, P., \& Watson, N. (1998). The Rise \& Stall of Teacher Education Reform. AACTE Publications.

Gansle, K. A., Noell, G. H., \& Burns, J. M. (2012). Do student achievement outcomes differ across teacher preparation programs? An analysis of teacher education in Louisiana. Journal of Teacher Education, 63(5), 304-317.

Goodlad, J. I. (1988). School-university partnerships for educational renewal: rationale and concepts. In K. A. Sirotnik \& J. I. Goodlad (Eds.), School-University Partnerships in Action: Concepts, Cases. (pp. 3-31). Teachers College Press.

Goodlad, J. L. (1990a). Connecting the present to the past. In J. Goodlad, R. Soder, \& K. Sirotnik (Eds.), Places where teachers are taught. (pp. 3-39). Jossey-Bass.

Goodlad, J. L. (1990b). Studying the education of educators: From conception to findings. The Phi Delta Kappan, 71(9), 698-701.

Goodlad, J. L. (1991). Why we need a complete redesign of teacher education. Educational Leadership, 49(3), 3-10.

Grossman, P. (2010). Learning to practice: The design of clinical experience in teacher preparation.

Grundy, S., Robison, J., \& Tomazos, D. (2001). Interrupting the way things are: Exploring new directions in school/university partnerships. Asia-Pacific Journal of Teacher Education, 29(3), 203-217.

Hathaway, W. E. (1985). Models of school-university collaboration: National and local perspectives on collaborations that work.

Holmes Group, Inc., East Lansing, MI. (1995). Tomorrow's schools of education [microform]: A report of the Holmes Group. Distributed by ERIC Clearinghouse. https://eric.ed.gov/?id=ED399220

Ilyenkov, E. V. (1977). Dialectical logic: Essays in its history and theory. Progress.

Jahreie, C. F., \& Ottesen, E. (2010). Construction of boundaries in teacher education: Analyzing student teachers' accounts. Mind, Culture, and Activity, 17(3), 212-234.

Jóhannsdóttir, T. (2010). Deviations from the conventional: Contradictions as sources of change in teacher education. In V. Ellis, A. Edwards, \& P. Smagorinsky (Eds.), Cultural historical perspectives on teacher education and development: learning teaching (pp.163-279). Routledge.

Kaptelinin, V. (2005). The object of activity: Making sense of the sense-maker. Mind, culture, and activity, 12(1), 4-18.

Korthagen, F. A., \& Kessels, J. P. (1999). Linking theory and practice: Changing the pedagogy of teacher education. Educational researcher, 28(4), 4-17.

Konkola, R., Tuomi-Gröhn, T., Lambert, P., \& Ludvigsen, S. (2007). Promoting learning and transfer between school and workplace. Journal of Education and Work, 20(3), 211-228.

Kuutti, K. (1996). Activity theory as a potential framework for human-computer interaction research. In B. Nardi (Ed.), Context and consciousness. (pp. 17-44). MIT Press.

Leont'ev, A. N. (1978). Activity, consciousness, and personality. Prentice-Hall.

Luria, A. R. (1979). The making of mind: A personal account of Soviet psychology. Harvard University Press.

Martin, S. D., Snow, J. L., \& Franklin Torrez, C. A. (2011). Navigating the terrain of third space: Tensions with/in relationships in school-university partnerships. Journal of Teacher Education, 62(3), 299-311.

Maxwell, J. A. (2012). Qualitative research design: An interactive approach (Vol. 41). Sage publications.

Merriam, S. B. (2009). Qualitative research: A guide to design and implementation. Jossey-Bass.

Miles, M. B., \& Huberman, A. M. (1994). Qualitative data analysis. (2nd ed.). Sage. 
Murrell Jr, P. C. (1998). Like stone soup: The role of the professional development school in the renewal of urban schools. AACTE Publications.

National Council for Accreditation of Teacher Education. (2010). Transforming teacher education through clinical practice: A national strategy to prepare effective teachers. Report of the Blue Ribbon Panel on Clinical Preparation and Partnerships for Improved Student Learning. Washington, DC: ERIC Clearinghouse.

Patton, M. Q. (1990). Qualitative evaluation and research methods. (2nd ed.). Sage.

Patton, M. Q. (2002). Qualitative evaluation and research methods. (3rd ed.). Sage.

Ragin, C. C., \& Amoroso, L. M. (2010). Constructing social research: The unity and diversity of method. Pine Forge Press.

Rogoff, B. (1990). Apprenticeship in Thinking. Cognitive Development in Social Context. Oxford University Press.

Rogoff, B. (1995). Observing sociocultural activity on three planes: Participatory appropriation, guided participation, and apprenticeship. In J. V. Wertsch, P. Del Rio, \& A. Alvarez (Eds.), Sociocultural studies of mind. (pp. 139-164). Cambridge University Press.

Roth, W. (2007). Emotion at work: A contribution to third-generation cultural-historical activity theory. Mind, Culture, and Activity, 14(1-2), 40-63.

Roth, W. (2012). Cultural-historical activity theory: Vygotsky's forgotten and suppressed legacy and its implication for mathematics education. Mathematics Education Research Journal, 24(1), 87-104.

Roth, W., \& Lee, Y. (2007). "Vygotsky's neglected legacy": Cultural-historical activity theory. Review of Educational Research, 77(2), 186-232.

Sannino, A., \& Engeström, Y. (2018). Cultural-historical activity theory: Founding insights and new challenges. Cultural-historical psychology.

Shinners, K. D. (2001). Public/private school partnerships: What can be learned from corporate school partnerships. Paper presented at the Annual Meeting of the American Educational Research Association, April 10-14, Seattle, WA.

Shulman, L. S. (1998). Theory, practice, and the education of professionals. The elementary school journal, 98(5), 511-526.

Smagorinsky, P., Cook, L. S., \& Johnson, T. S. (2003). The twisting path of concept development in learning to teach. Teachers College Record, 105(8), 1399-1436.

Stetsenko, A. (2019) Radical-Transformative Agency: Continuities and contrasts with relational agency and implications for education. Frontiers in Education (Vol. 4, p. 148). Frontiers.

Stetsenko, A. (2020). Radical-transformative agency: Developing a transformative activist stance on a Marxist-Vygotskyan foundation. In Neto, Liberali, Dafermos (Eds.), Revisiting Vygotsky for social change (31-62). London: Peter Lang.

Stetsenko, A. P. (2020). Critical Challenges in Cultural-Historical Activity Theory: The Urgency of Agency. Cultural-Historical Psychology, 16(2), 5-18.

St. John, E., Goldhaber, D., Krieg, J., \& Theobald, R. (2018). How the match gets made: Exploring student teacher placements across teacher education programs, districts, and schools. CALDER Working Paper 111018.

Stake, R. E. (2006). Multiple case study analysis. The Guilford Press.

Teitel, L. (1997). Changing teacher education through professional development school partnerships: A five-year follow-up study. Teachers College Record, 99(2), 23.

Toiviainen, H. (2007). Inter-organizational learning across levels: an object-oriented approach. Journal of Workplace Learning, 19(6), 343-358.

Valencia, S. W., Martin, S. D., Place, N. A., \& Grossman, P. (2009). Complex interactions in student teaching: Lost opportunities for learning. Journal of Teacher Education, 60(3), 304-322.

Vick, M. (2006). "It's a Difficult Matter": Historical perspectives on the enduring problem of the practicum in teacher preparation. Asia-Pacific Journal of Teacher Education, 34(2), 181-198.

Vygotsky, L. S. (1978). Mind in society: The development of higher mental process. (Cole, M., John-Steiner, V., Scribner, S., \& Souberman, E., Eds) (Revised edition). Cambridge: Harvard University Press.

Windschitl, M., Thompson, J., \& Braaten, M. (2011). Ambitious pedagogy by novice teachers: Who benefits from tool-supported collaborative inquiry into practice and why? Teachers College Record, 113(7), 1311-1360.

Wilson, V. (2014). Examining teacher education through cultural-historical activity theory. Teacher Education Advancement Network Journal, 6, 20-29.

Yamagata-Lynch, L. C. (2010). Understanding cultural historical activity theory. In Activity systems analysis methods (pp. 13-26). Springer US.

Yamagata-Lynch, L. C., \& Haudenschild, M. T. (2008). Teacher perceptions of barriers and aids of professional growth in professional development. School-University Partnerships, 2(2), 90-106. 
Yamazumi, K. (2006). Activity theory and the transformation of pedagogic practice. Educational Studies in Japan: International Yearbook, 1, 77-90.

Yin, R. K. (2008). Case Study Research: Design and Methods. (4th ed.). SAGE Publications Inc.

Zeichner, K. (1996). Designing educative practicum experiences for prospective teachers. Currents of reform in preservice teacher education, 215-234.

Zeichner, K. (2007). Accumulating knowledge across self-studies in teacher education. Journal of teacher education, 58(1), 36-46.

Zeichner, K. (2009). Professional development schools in a culture of evidence and accountability. Teacher Education and the Struggle for Social Justice (pp. 64-73). Routledge.

Zeichner, K. (2010). Rethinking the connections between campus courses and field experiences in collegeand university-based teacher education. Journal of teacher education, 61(1-2), 89-99.

Zeichner, K. (2012). The turn once again toward practice-based teacher education. Journal of teacher education, 63(5), 376-382.

Zeichner, K., \& Conklin, H. G. (2005)."Teacher Education Programs," pp. 645-735 in Cockran-Smith, M. and Zeichner, K. (Eds.), Studying Teacher Education. Mahwah, NJ: Lawrence Erlbaum, 2005.

Zeichner, K., Payne, K. A., \& Brayko, K. (2015). Democratizing teacher education. Journal of Teacher Education, 66(2), 122-135.

Publisher's Note Springer Nature remains neutral with regard to jurisdictional claims in published maps and institutional affiliations. 